\title{
METODE EXTREME PROGRAMMING PADA PEMBANGUNAN WEB APLIKASI SELEKSI PESERTA PELATIHAN KERJA
}

\author{
Adi Supriyatna \\ Manajemen Informatika \\ AMIK BSI Karawang \\ adi.asp@bsi.ac.id
}

\begin{abstract}
ABSTRAK
Balai Latihan Kerja secara umum merupakan gedung atau sarana yang digunakan sebagai tempat berlatih dan menambah keterampilan untuk mempersiapkan diri dalam memasuki dunia kerja. Saat ini proses penerimaan dan ujian seleksi peserta pelatihan kerja pada balai latihan kerja masih dilakukan dengan cara konvensional, peserta harus mendatangi lokasi balai latihan kerja untuk melakukan pendaftaran dan mengikuti ujian seleksi, dampaknya hal ini menjadi salah satu hambatan bagi masyarakat yang ingin mengikuti program pelatihan kerja. Selain itu kurangnya penyebaran informasi kepada masyarakat tentang periode penerimaan peserta pelatihan kerja yang dilaksanakan oleh balai latihan kerja. Penelitian ini bertujuan untuk menciptakan sebuah aplikasi berbasis web dengan menggunakan metode Extreme Programming (XP) yang bermanfaat bagi masyarakat untuk memudahkan dalam proses pendaftaran dan pelaksanaan ujian seleksi menjadi peserta pelatihan kerja. Serta diharapkan dapat meminimalkan hambatan yang selama ini terjadi. Dalam pengembangan perangkat lunak terdapat beberapa pendekatan atau metode yang digunakan, dalam penelitian ini metode yang digunakan adalah Extreme Programming (XP) untuk membangun aplikasi seleksi peserta pelatihan kerja. Extreme Programming (XP) merupakan sebuah proses rekayasa perangkat lunak yang cenderung menggunakan pendekatan berorientasi objek dan sasaran dari metode ini adalah tim yang dibentuk dalam skala kecil sampai medium serta metode ini juga sesuai jika tim dihadapkan dengan requirement yang tidak jelas maupun terjadi perubahan-perubahan requirement yang sangat cepat. Hasil penelitian ini berupa aplikasi penyebaran informasi dan ujian seleksi peserta pelatihan berbasis web yang dapat memberikan kemudahan kepada calon peserta untuk mendapatkan informasi terkait balai latihan kerja, melakukan pendaftaran sampai dengan melakukan ujian seleksi.
\end{abstract}

Kata Kunci: Balai Latihan Kerja, Extreme Programming (XP), Seleksi

\begin{abstract}
Training Center in general is a building or a means used as a place to practice and add skills to prepare yourself in entering the workforce. Currently the process of acceptance and examination of the selection of training participants at the vocational training center is still done in the conventional way, the participants must go to the vocational training center to enroll and take the selection test, the impact of this becomes one of the obstacles for people who want to join the job training program. In addition, the lack of dissemination of information to the public about the period of acceptance of training participants conducted by the vocational training center. This study aims to create a webbased application using Extreme Programming (XP) method that is useful for the community to facilitate the registration process and implementation of the selection test to be a work-training participant. And expected to minimize the barriers that have been happening. In the software development there are several approaches or methods used, in this study the method used is Extreme Programming (XP) to build application selection of training participants. Extreme Programming (XP) is a software engineering process that tends to use object oriented approach and the target of this method is a team formed on a small to medium scale and this method is also appropriate if the team faced with unclear requirements as well as changes in requirement changes which is very fast. The results of this research is the application of information dissemination and selection test of web-based training participants that can give ease to prospective participants to get information related to work training center, registering up to do the selection test.
\end{abstract}


Keywords: Training Centre, Extreme Programming (XP), Selection

DOI : 10.15408/jti.v11i1.6628

\section{PENDAHULUAN}

Balai Latihan Kerja secara umum merupakan gedung atau sarana yang digunakan sebagai tempat berlatih dan menambah keterampilan untuk mempersiapkan diri dalam memasuki dunia kerja. Pelatihan yang diadakan oleh Balai Latihan Kerja berguna untuk membekali keterampilan kepada peserta dalam berbagai bidang kejuruan dan memberikan motivasi untuk berusaha mandiri. Adapun sasaran kegiatan ini adalah terciptanya tenaga kerja yang terampil, disiplin, dan memiliki etos kerja produktif sehingga mampu mengisi kesempatan kerja yang ada dan mampu menciptakan lapangan kerja melalui usaha mandiri. Balai Latihan Kerja dirancang untuk memenuhi kebutuhan masyarakat akan lembaga pelatihan kerja yang berdedikasi mencetak tenaga kerja yang siap terjun ke dalam dunia kerja.

Pusat Pelatihan kerja Pengembangan Industri yang selanjutnya disingkat dengan PPKPI adalah merupakan Unit Pelaksanan Teknis Dinas Tenaga Kerja (UPTD) ditingkat Provinsi DKI Jakarta yang dibentuk berdasarkan peraturan Gubernur Provinsi DKI Jakarta 115 Tahun 2010 tentang Pembentukan Organisasi dan Tata Kerja Pusat Pelatihan Kerja Pengembangan Industri (PPKPI) yang berdiri sejak tahun 1956 di bawah Kementerian Perburuhan Republik Indonesia.

Saat ini proses penerimaan dan ujian seleksi peserta pelatihan kerja pada balai latihan kerja masih dilakukan dengan cara konvensional yaitu peserta harus mendatangi lokasi balai latihan kerja berada untuk melakukan pendaftaran dan mengikuti ujian seleksi, dampaknya hal ini menjadi salah satu hambatan bagi masyarakat yang ingin mengikuti program pelatihan kerja dikarenakan lokasi tempat tinggalnya jauh dengan balai latihan kerja. Selain itu kurangnya penyebaran informasi kepada masyarakat tentang periode penerimaan peserta pelatihan kerja yang dilaksanakan oleh balai latihan kerja.

Penelitian ini bertujuan untuk menciptakan sebuah aplikasi berbasis web dengan menggunakan metode Extreme Programming (XP) yang bermanfaat bagi masyarakat untuk memudahkan dalam proses pendaftaran dan pelaksanaan ujian seleksi menjadi peserta pelatihan kerja. Serta diharapkan dapat meminimalkan hambatan yang selama ini terjadi.

\section{TINJAUAN PUSTAKA}

Pelatihan didefinisikan sebagai usaha untuk meningkatkan kinerja pegawai dalam melaksanakan pekerjaannya saat ini atau dalam pekerjaan lain yang akan dijabatnya segera [1]. Pelatihan juga merupakan Proses mengajarkan karyawan baru atau yang ada sekarang, ketrampilan dasar yang mereka butuhkan untuk menjalankan pekerjaan mereka [2].

Sistem adalah kumpulan/group dari sub sistem/bagian/komponen apapun baik phisik ataupun non phisik yang saling berhubungan satu sama lain dan bekerja sama secara harmonis untuk mencapai satu tujuan tertentu [3]. Sistem Informasi adalah suatu sistem yang terdiri dari kumpulan komponen sistem, yaitu software, hardware dan brainware yang memproses informasi menjadi sebuah keluaran/output yang berguna untuk mencapai suatu tujuan tertentu dalam organisasi [4].

Seleksi adalah usaha menjaring dari mereka yang dianggap nantinya bisa menyesuaikan diri dengan pekerjaan yang ditawarkan, mereka dianggap dapat memperlihatkan unjuk kerja yang diharapkan oleh para pimpinan organisasi [5].

Extreme Programming (XP) adalah metode pengembangan perangkat lunak yang sederhana dan mencakup salah satu metode tangkas yang dipelopori oleh Kent Beck, Ron Jeffries, dan Ward Cunningham. XP adalah salah satu metode tangkas yang paling banyak digunakan dan menjadi pendekatan yang sangat terkenal. Tujuan XP adalah tim yang terbentuk antara kursus berukuran kecil hingga menengah, tidak perlu menggunakan tim besar. Hal ini dimaksudkan untuk mengatasi persyaratan yang tidak jelas dan perubahan persyaratan dengan sangat cepat [6].

Unified Modeling Language (UML) adalah bahasa pemodelan untuk sistem atau perangkat lunak yang berparadigma berorientasi objek. Pemodelan (modeling) sesungguhnya digunakan untuk penyederhanaan permasalahan-permasalahan yang kompleks sedemikian rupa sehingga lebih mudah dipelajari dan dipahami [7]. 


\section{METODOLOGI}

Dalam pengembangan perangkat lunak terdapat beberapa pendekatan atau metode yang digunakan, dalam penelitian ini metode yang digunakan adalah Extreme Programming $(X P)$ untuk membangun aplikasi seleksi peserta pelatihan kerja. Extreme Programming $(X P)$ merupakan sebuah proses rekayasa perangkat lunak yang cenderung menggunakan pendekatan berorientasi objek dan sasaran dari metode ini adalah tim yang dibentuk dalam skala kecil sampai medium serta metode ini juga sesuai jika tim dihadapkan dengan requirement yang tidak jelas maupun terjadi perubahan-perubahan requirement yang sangat cepat [8].

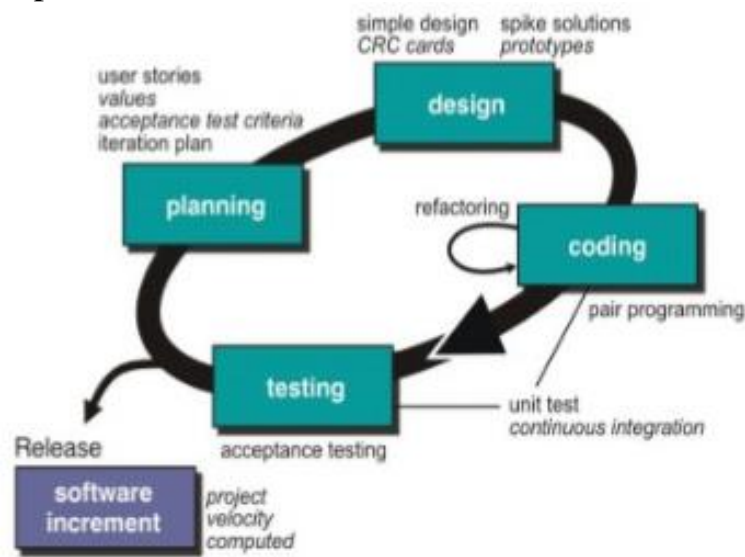

Gambar 1. Skema XP practices

Adapun tahapan pembangunan aplikasi web seleksi peserta pelatihan kerja dengan XP adalah sebagai berikut:

\section{Planning (Perencanaan)}

Tahapan ini dimulai dengan mendengarkan kumpulan kebutuhan aktifitas suatu sistem yang memungkinkan pengguna memahami proses bisnis untuk sistem dan mendapatkan gambaran yang jelas mengenai fitur utama, fungsionalitas dan keluaran yang diinginkan. Dalam pembangunan aplikasi web seleksi peserta pelatihan kerja pada tahapan ini dimulai dari mengidentifikasi permasalahan yang timbul pada sistem yang sedang berjalan, kemudian dilakukan analisa kebutuhan pengguna terhadap sistem yang akan dibangun.

2. Design (Perancangan)

Pada tahapan perancangan dilakukan pembuatan pemodelan sistem berdasarkan hasil analisa kebutuhan yang didapatkan. Selain itu dibuatkan juga pemodelan basis data untuk menggambarkan hubungan antar data. Pemodelan sistem yang digunakan yaitu Unified Modelling Language (UML) yang terdiri dari beberapa diagram antara lain Use-Case Diagram, Activity Diagram, Component Diagram dan Deployment Diagram. Sedangkan untuk pemodelan basis data menggunakan Entity Relationship Diagram (ERD) dan Logical Record Structure (LRS).

3. Coding (Pengkodean)

Tahapan ini merupakan implementasi dari perancangan model sistem yang telah dibuat kedalam kode program yang menghasilkan prototipe dari perangkat lunak. Dalam pembangunan aplikasi web seleksi peserta pelatihan kerja menggunakan bahasa pemrograman PHP yang dikombinasikan dengan HTML, CSS dan Javascript. Untuk implementasi basis data, Database Management System yang digunakan adalah MySQL.

4. Testing (Pengujian)

Tahapan ini merupakan tahapan pengujian terhadap aplikasi yang sudah dibangun, pada tahapan ini ditentukan oleh pengguna sistem dan berfokus pada fitur dan fungsionalitas dari keseluruhan sistem kemudian ditinjau oleh pengguna sistem. Metode yang digunakan dalam melakukan pengujian terhadap aplikasi web seleksi peserta pelatihan kerja adalah Black-Box Testing dengan melakukan pengujian terhadap masukkan dan keluaran yang dihasilkan sistem.

5. Software Increment (Peningkatan Perangkat Lunak.

Tahapan ini merupakan tahap pengembangan sistem yang sudah dibuat secara bertahap yang dilakukan setelah sistem diterapkan dalam organisasi dengan menambahkan layanan atau konten yang mengakibatkan bertambahnya kemampuan fungsionalitas dari sistem.

\section{HASIL DAN PEMBAHASAN}

\subsection{Penelitian Terkait}


Seiring dengan perkembangan teknologi informasi dan adanya kebutuhan sumber daya manusia dalam organisasi bisnis semakin meningkat. Maka dari itu, dibutuhkan suatu sistem informasi yang dapat mendukung upaya optimasi dalam proses rekrutmen dan seleksi karyawan. PT. Qwords Company International sebagai perusahaan yang bergerak di bidang IT dan juga merupakan perusahaan yang sedang berkembang, saat ini proses rekrutmen dan seleksi karyawannya masih menggunakan metode manual dan juga menggunakan kertas. Hal tersebut dapat menimbulkan beberapa permasalahan di antaranya, banyaknya data pelamar yang hilang atau rusak, dan menghabiskan cukup banyak waktu dalam proses rekrutmen dan seleksi karyawannya. Penelitian ini menghasilkan sebuah rancangan sistem informasi rekrutmen dan seleksi karyawan dengan menggunakan metode waterfall dan diagram Unified Modeling Language (UML) yang dapat digunakan sebagai dasar untuk dilakukannya implementasi dari sistem informasi rekrutmen dan seleksi tersebut untuk dijadikan solusi dar permasalahan yang ada [9].

Proses pengelolaan nilai hasil seleksi asisten laboratorium Jurusan Teknik Informatika UII selama ini masih dilakukan secara manual, sehingga masih banyak membutuhkan tenaga terutama untuk mengkompilasi data nilai hasil seleksi. Oleh sebab itu dirasa perlu untuk mengembangkan suatu sistem informasi manajemen rekruitmen calon asisten laboratorium informatika terpadu yang mampu mengelola pendaftaran, penilaian pada setiap tahap proses seleksi dan nilai akhir hasil rekruitmen menjadi lebih baik dan terstruktur. Metode yang dipakai adalah metode waterfall, yang bertujuan untuk mengembangkan metode kerja yang efektif sesuai dengan tahapan-tahapan yang dibutuhkan. Dan sistem yang dikembangkan adalah sistem yang dapat mengkompilasi nilai akhir dengan mempertimbangkan nilai pada setiap tahap proses seleksi serta berbasis pada konfigurasi pembobotan nilai disetiap tahap seleksi [10].

\subsection{Hasil Penelitian}

\subsubsection{Planning (Perencanaan)}

1. Identifikasi Permasalahan.

Permasalahan yang timbul saat ini adalah belum adanya sistem yang dapat digunakan untuk melakukan pendaftaran dan seleksi peserta pelatihan kerja.
Penyebaran informasi terkait pembukaan pelatihan kerja masih kurang optimal karena masih dilakukan dengan cara konvensional.

2. Analisa Kebutuhan.

a. Calon peserta dapat melihat informasi pendaftaran.

b. Calon peserta dapat melakukan pendaftaran peserta pelatihan.

c. Calon Peserta dapat login.

d. Calon Peserta dapat mengikuti ujian seleksi.

e. Calon Peserta dapat melakukan verifikasi data.

f. Admin dapat login.

g. Admin dapat manajemen data periode.

h. Admin dapat manajemen data program.

i. Admin dapat manajemen data peserta.

j. Admin dapat menajemen data soal.

k. Admin dapat mencetak laporan.

\subsubsection{Design (Perancangan)}

1. Pemodelan Sistem

a. Use-Case Diagram Calon Peserta

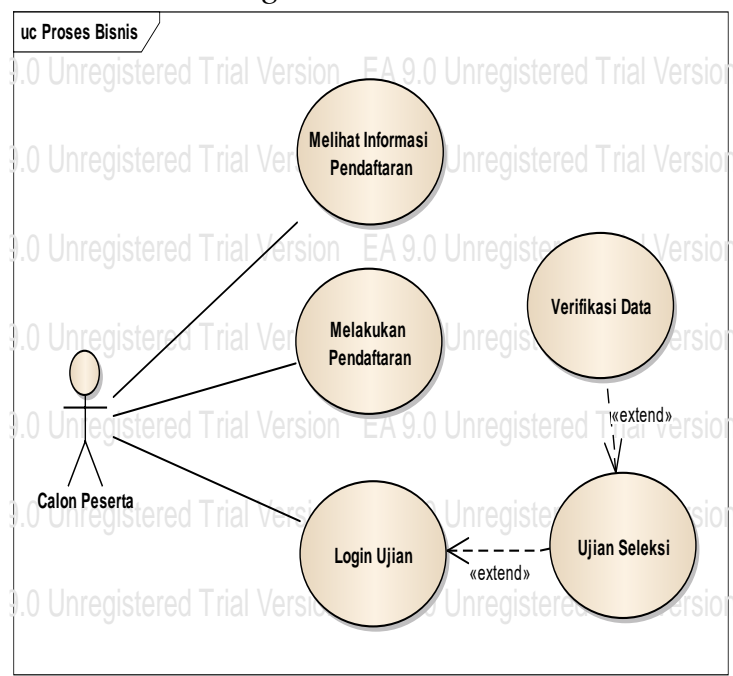

Gambar 2. Use case diagram calon peserta

Diagram diatas menggambarkan mengenai fungsi dari aplikasi seleksi peserta yang dapat digunakan oleh calon peserta, dimana calon peserta dapat melihat informasi pendaftaran, melakukan pendaftaran, masuk ke ruang ujian dan mengikuti ujian seleksi 
b. Use-Case Diagram Admin

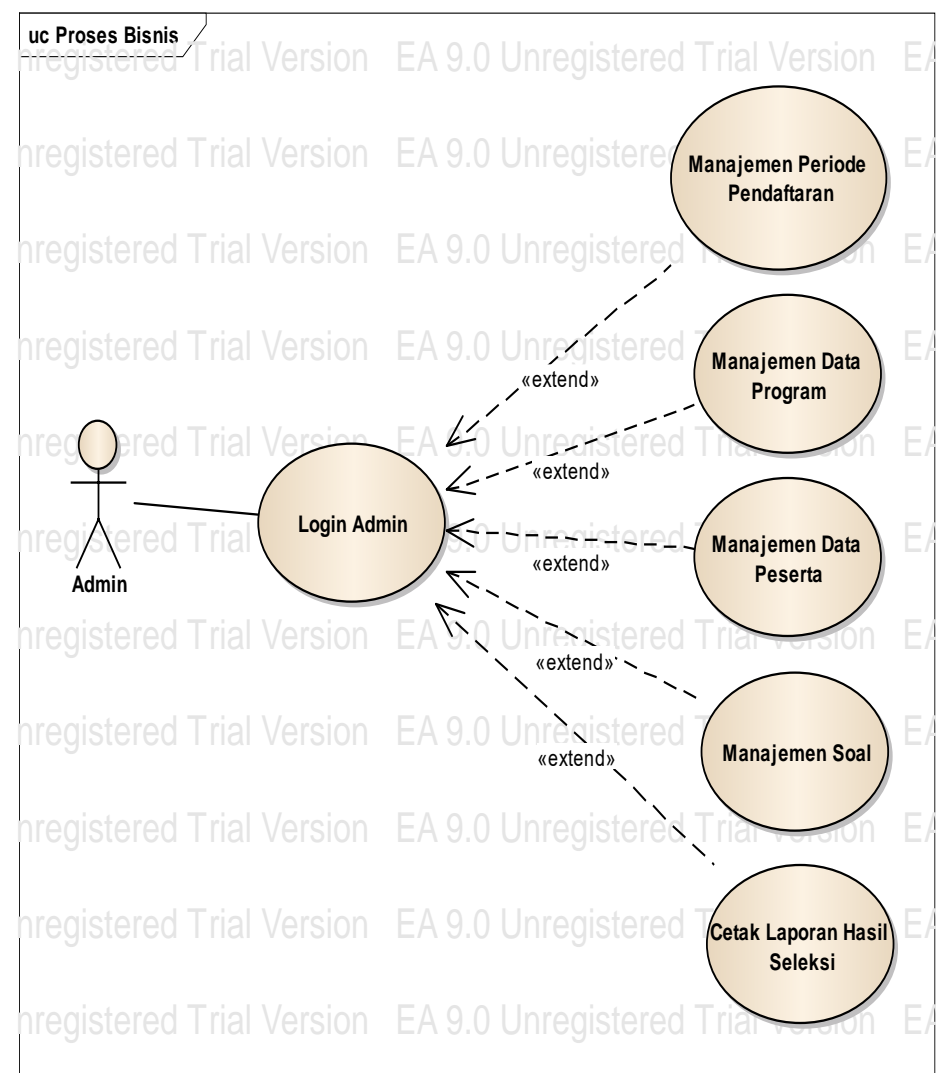

Gambar 3. Use case diagram admin

Use Case diagram admin menggambarkan fungsi atau layanan apa saja yang bisa digunakan oleh administrator dari aplikasi ujian seleksi. Untuk melakukan manajemen data pengguna admin diharuskan melakukan login, jika berhasil maka akan masuk kehalaman administrator. Dalam halaman administrator dalam dilakukan pengolahan data periode, data program, data peserta, data soal sampai dengan mencetak laporan hasil seleksi. 
c. Activity Diagram Pendaftaran

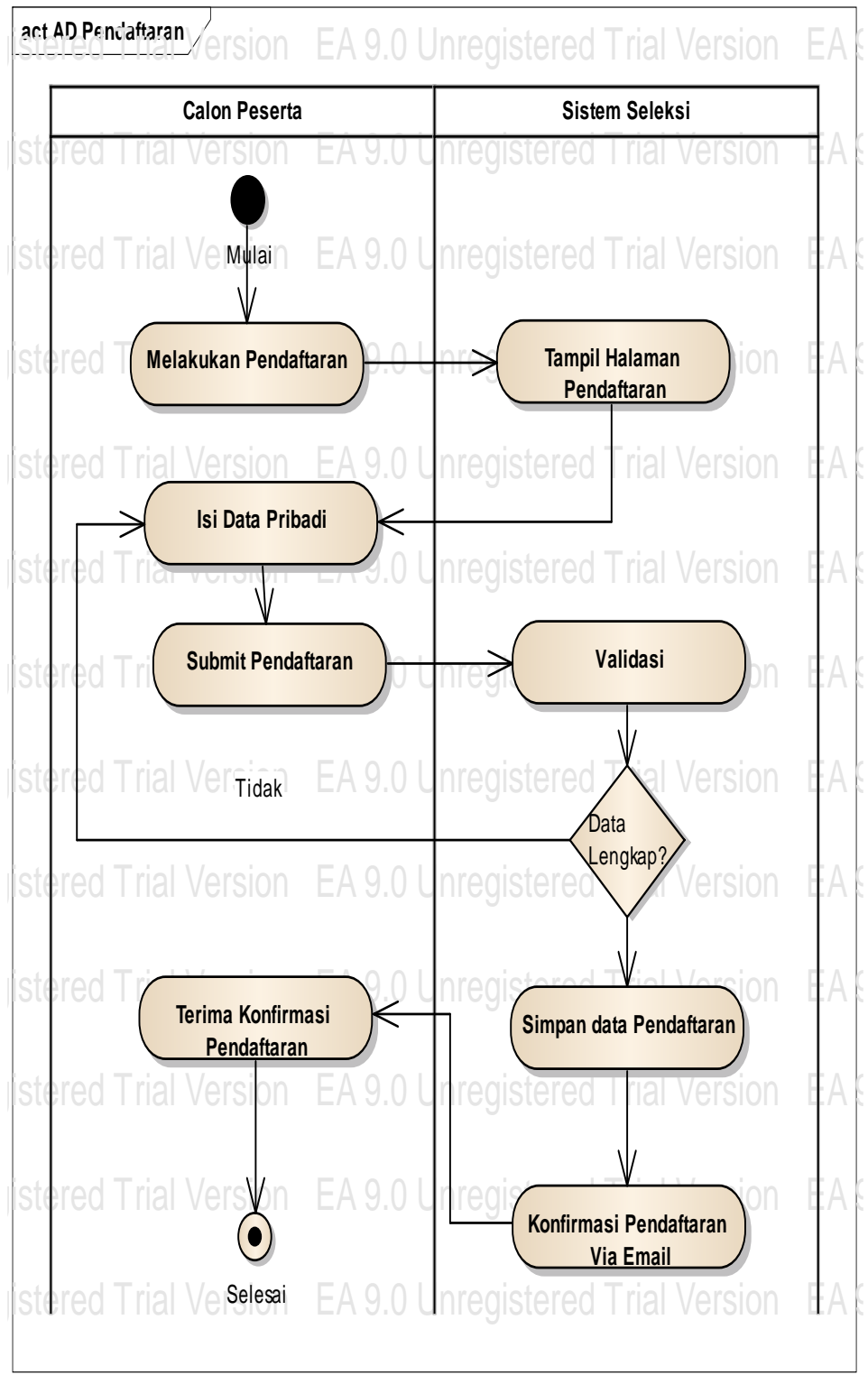

Gambar 4. Activity diagram pendaftaran

Calon peserta yang ingin melakukan pendaftaran membuka menu pendaftaran kemudian sistem menampilkan halaman pendaftaran, calon peserta harus mengisi data dengan lengkap sesuai dengan elemen data yang diminta kemudian klik submit, selanjutnya sistem melakukan validasi kelengkapan data, jika sudah lengkap sistem akan menyimpan data dan konfirmasi pendaftaran melalui email yang berisi username dan password untuk login ke ruang ujian. 
d. Activity Diagram Ujian Seleksi

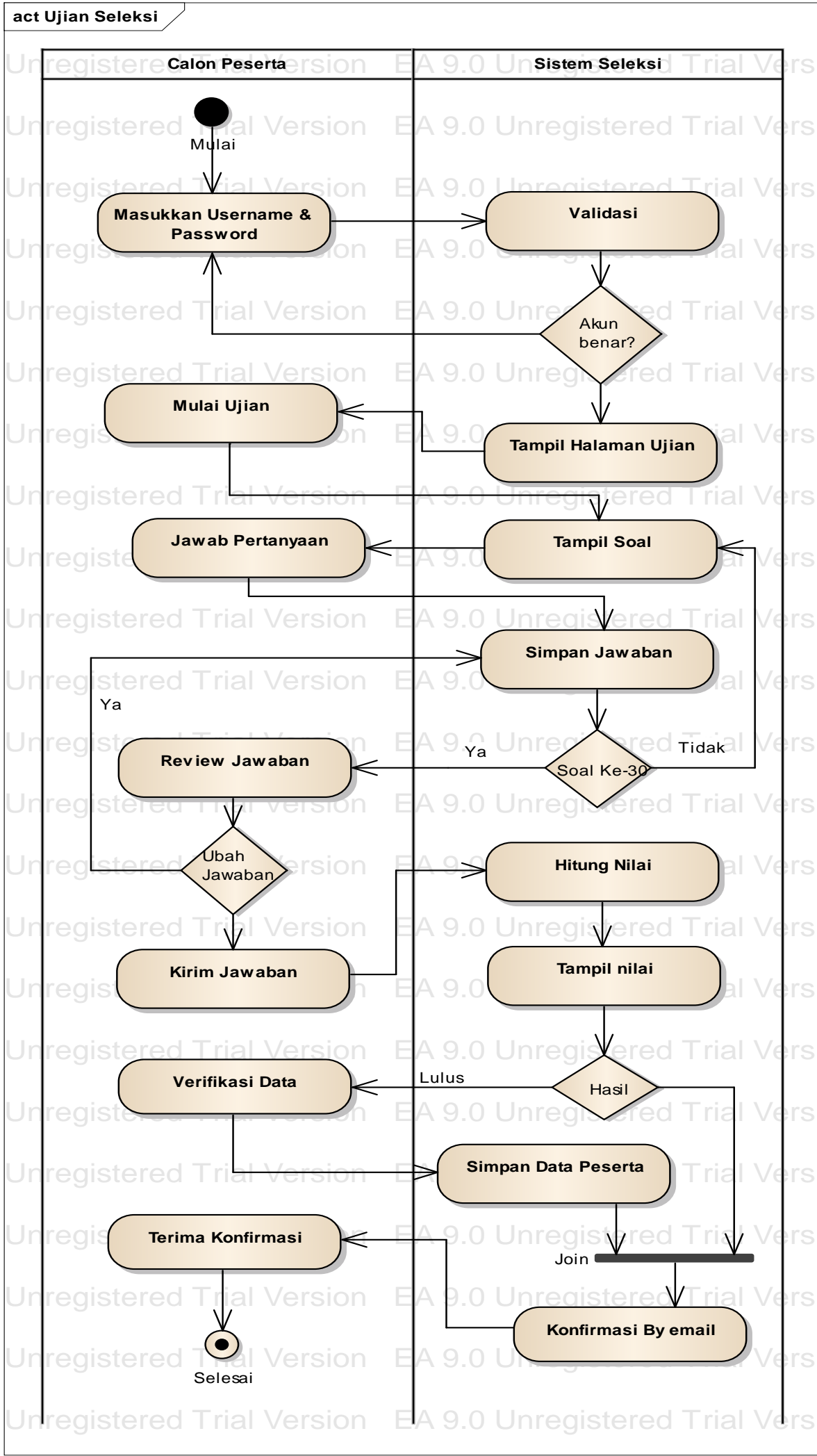

Gambar 5. Activity diagram ujian seleksi

Untuk mengikuti ujian seleksi calon peserta diwajibkan melakukan login ke ruang ujian dengan menggunakan username dan password yang didapatkan pada saat melakukan pendaftaran, jika login berhasil maka calon peserta akan diarahkan ke ruang 
ujian. Untuk memulai ujian dilakukan dengan klik menu mulai ujian kemudian sistem akan menampilkan halaman pertanyaan calon peserta harus memilih jawaban yang tersedia dengan benar dan sistem menyimpan jawaban sementara, soal yang ditampilkan berjumlah 30 pertanyaan. Jika semua pertanyaan sudah dijawab calon peserta dapat melakukan review jawaban dan merubah jawaban. Untuk menyelesaikan ujian calon peserta klik tombol kirim jawaban kemudian sistem akan menghitung nilai dan menampilkan hasil ujian.
Jika dinyatakan gagal maka calon peserta akan mendapatkan konfirmasi melalui email tentang kegagalan tersebut, namun jika dinyatakan berhasil calon peserta wajib melakukan verifikasi data dan sistem menyimpan data yang sudah diverifikasi, sistem akan mengirimkan konfirmasi melalui email Nomor Induk Peserta dan password untuk masuk kehalaman peserta.

\section{e. Activity Diagram Manajemen Data Peserta}

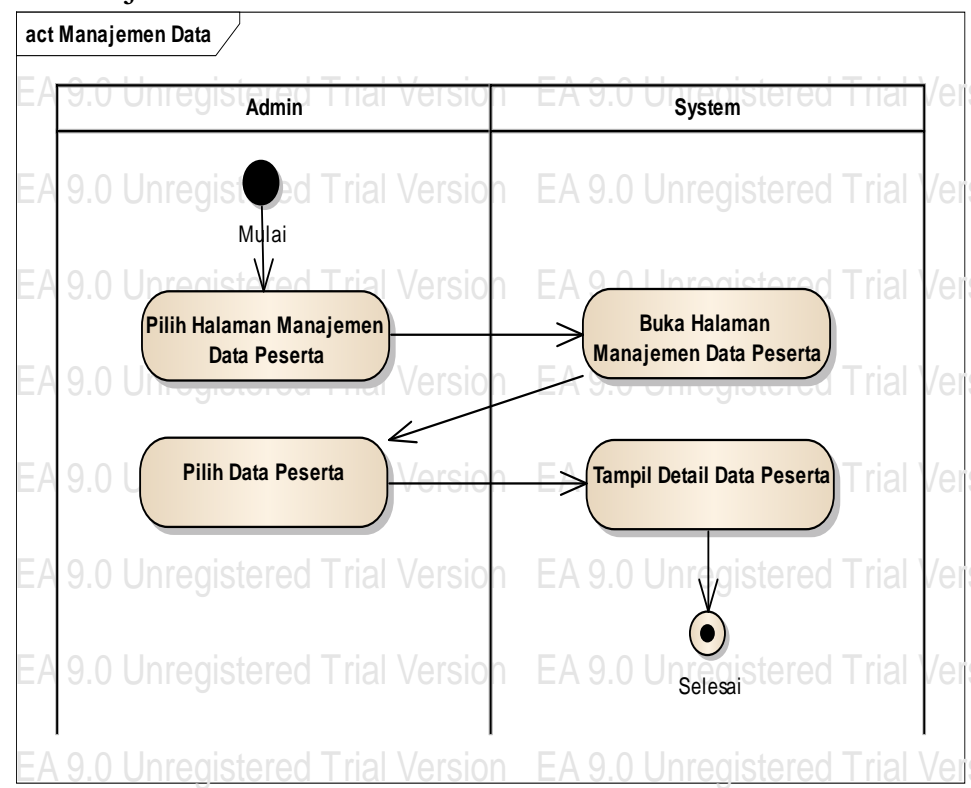

Gambar 6. Activity diagram manajemen data peserta

Untuk melakukan pengolahan data peserta, administrator memilih menu halaman manajemen data peserta maka sistem akan menampilkan halaman data peserta, kemudian pilih data peserta yang ingin dilihat maka sistem menampilkan detail data peserta pelatihan kerja. 
f. Activity Diagram Manajemen Data Soal

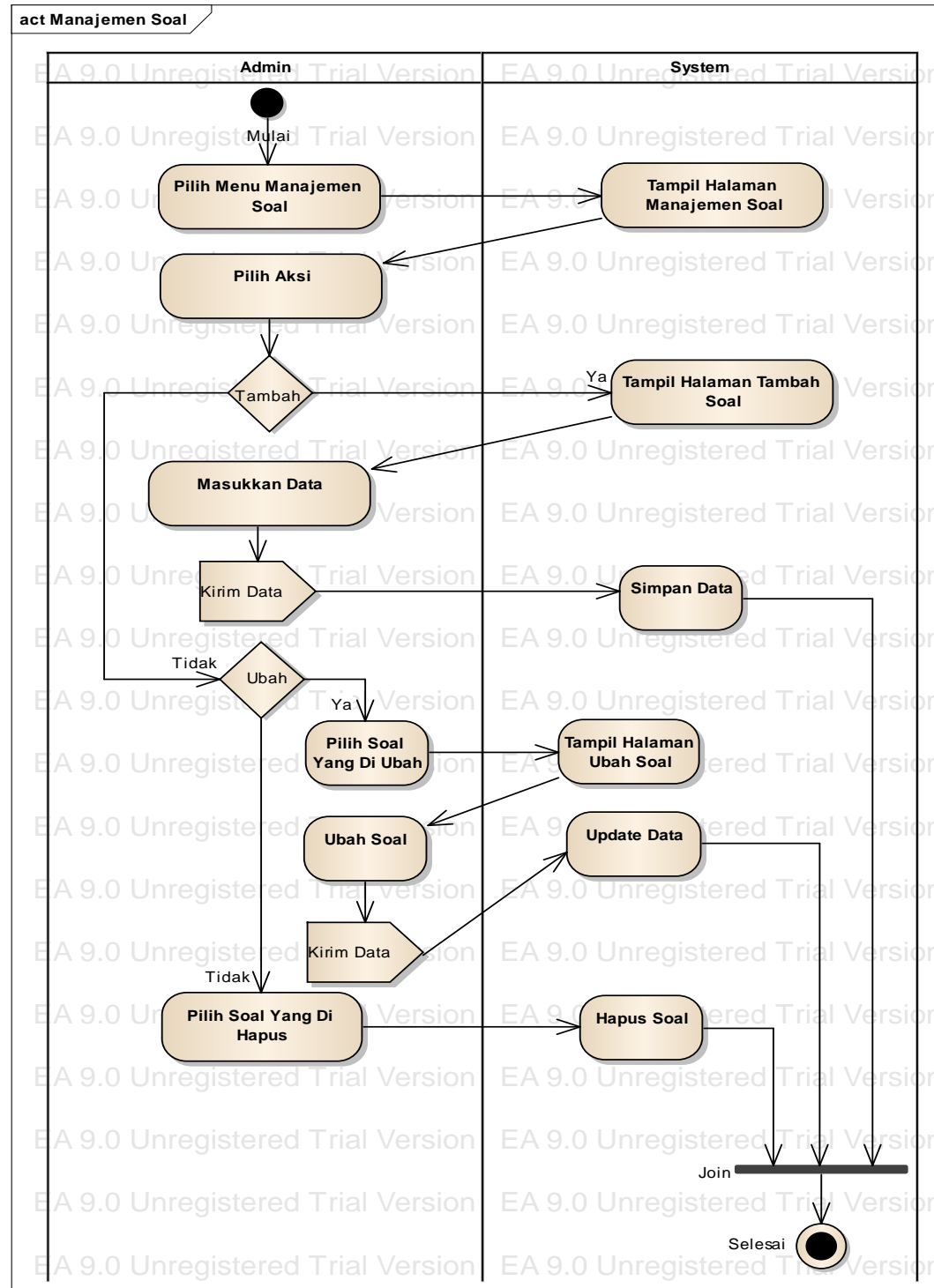

Gambar 7. Activity diagram manajemen soal

Untuk melakukan pengolahan data soal admin harus membuka halaman manajemen data soal dan sistem akan menampilkan halaman manajemen data soal, untuk menambah soal baru dilakukan dengan menekan tombol tambah kemudian sistem menampilkan form tambah soal kemudian admin memasukkan data dan klik simpan maka sistem akan menyimpan data soal baru. Untuk melakukan perubahan data klik tombol ubah pada data soal yang akan diubah, sistem akan menampilkan form ubah data soal yang dipilih, setelah melakukan perubahan kemudian admin klik tombol update untuk memperbarui data soal dan sistem menyimpan data soal yang diubah. Sedangkan untuk menghapus admin klik tombol hapus pada data soal kemudian sistem akan menghapus data soal yang dihapus tersebut. 


\section{Perancangan Arsitektur Sistem}

a. Component Diagram

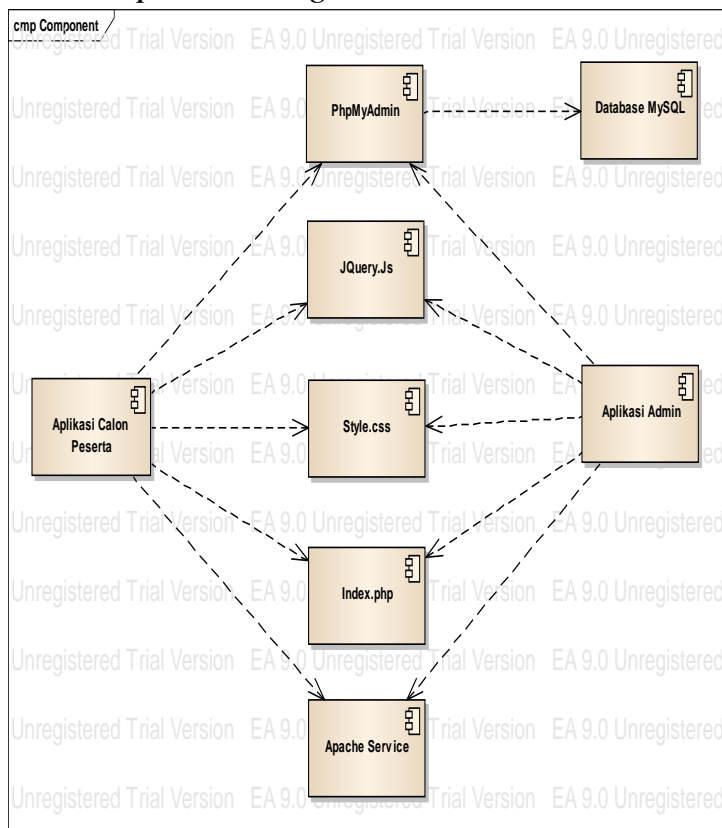

Gambar 8. Component diagram aplikasi ujian seleksi peserta pelatihan kerja

Component Diagram di atas menggambarkan mengenai arsitektur aplikasi seleksi peserta pelatihan kerja berbasis web dimana terdapat dua pengguna yaitu aplikasi calon peserta dan aplikasi admin. Kedua pengguna tersebut dibangun dengan menggunakan beberapa komponen yaitu Apache Service, Bahasa Pemrograman PHP, CSS dan Jquery. Untuk basis data menggunakan editor PhpMyAdmin dengan sistem manajemen basis data yang digunakan adalah MySQL.

\section{b. Deployment Diagram}

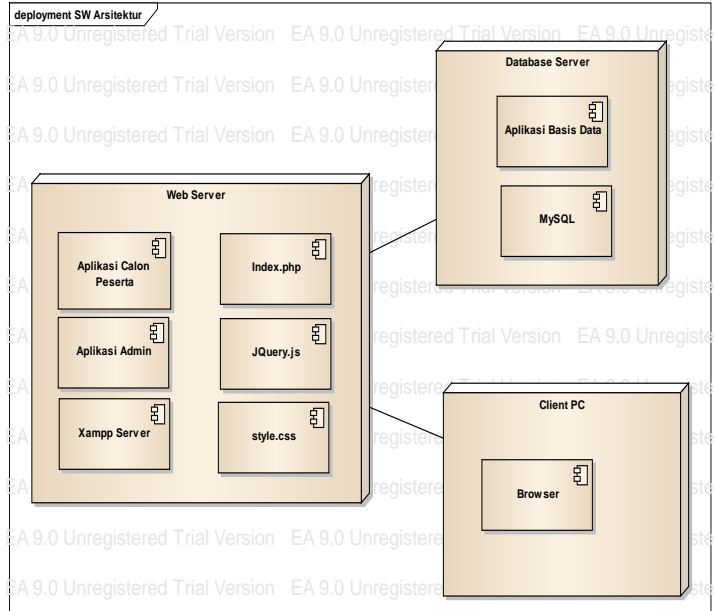

Gambar 9. Deployment diagram aplikasi ujian seleksi peserta pelatihan kerja

Deployment diagram di atas menggambarkan pemetaan perangkat lunak ke processing node. Dari diagram diatas dapat dijelakan bahwa aplikasi seleksi peserta pelatihan kerja berbasis web dibagi menjadi 3 node yaitu web server yang didalamnya terdiri dari aplikasi calon peserta, aplikasi admin, apache service, PHP, Jquery dan CSS. Node yang kedua adalah Client $P C$ menjelaskan untuk penggunaan aplikasi ini dilakukan menggunakan web browser seperti firefox, chrome, opera, dan lain-lainl. Node yang ketiga adalah Database Server yang terdiri dari aplikasi basis data yaitu PhpMyAdmin dan sistem manajemen basis data menggunakan perangkat lunak MySQL. 


\section{Pemodelan Basis Data}

a. Entity Relationship Diagram (ERD)

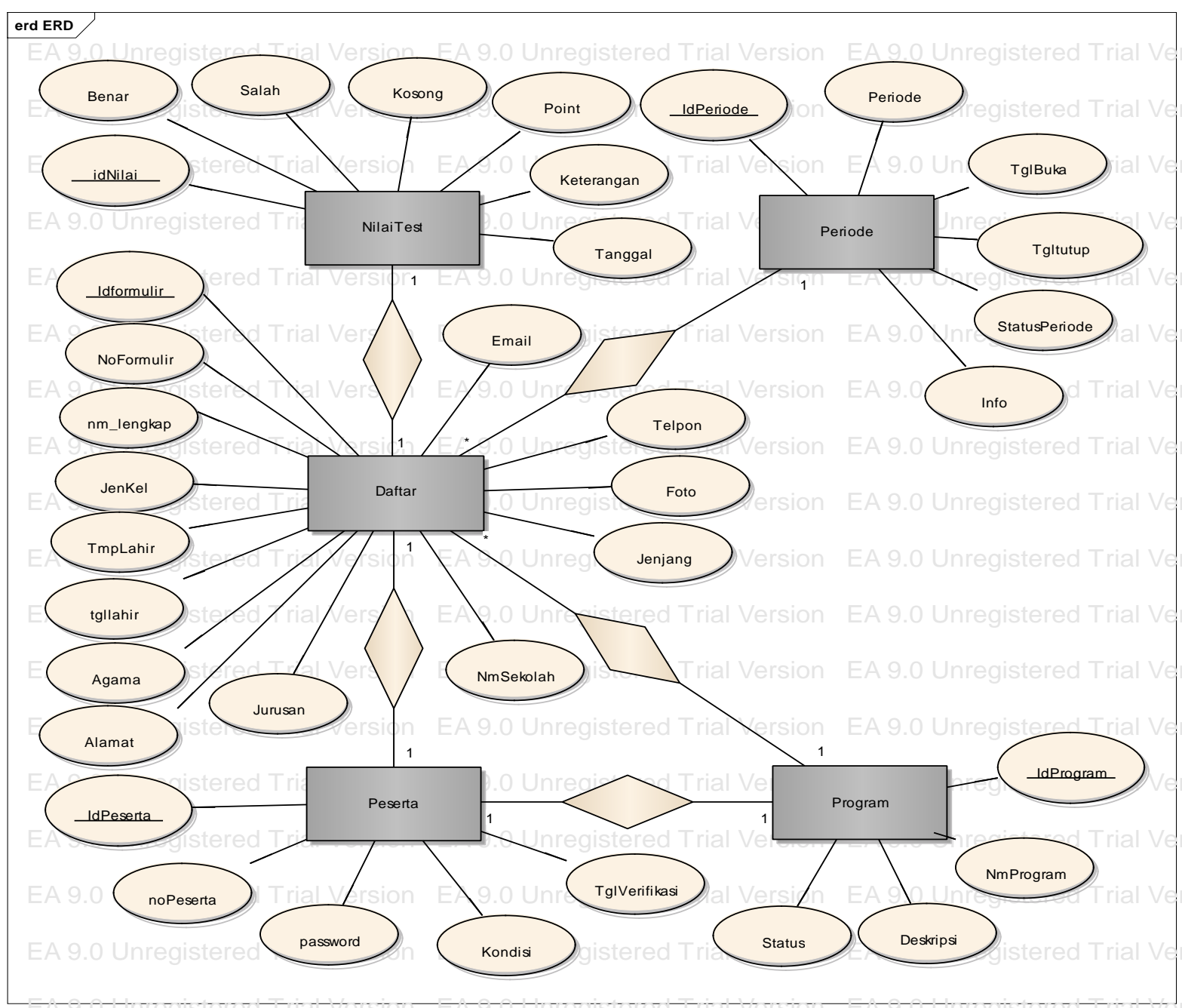

Gambar 9. Entity relationship diagram aplikasi seleksi peserta pelatihan kerja 
b. Logical Record Structure (LRS)

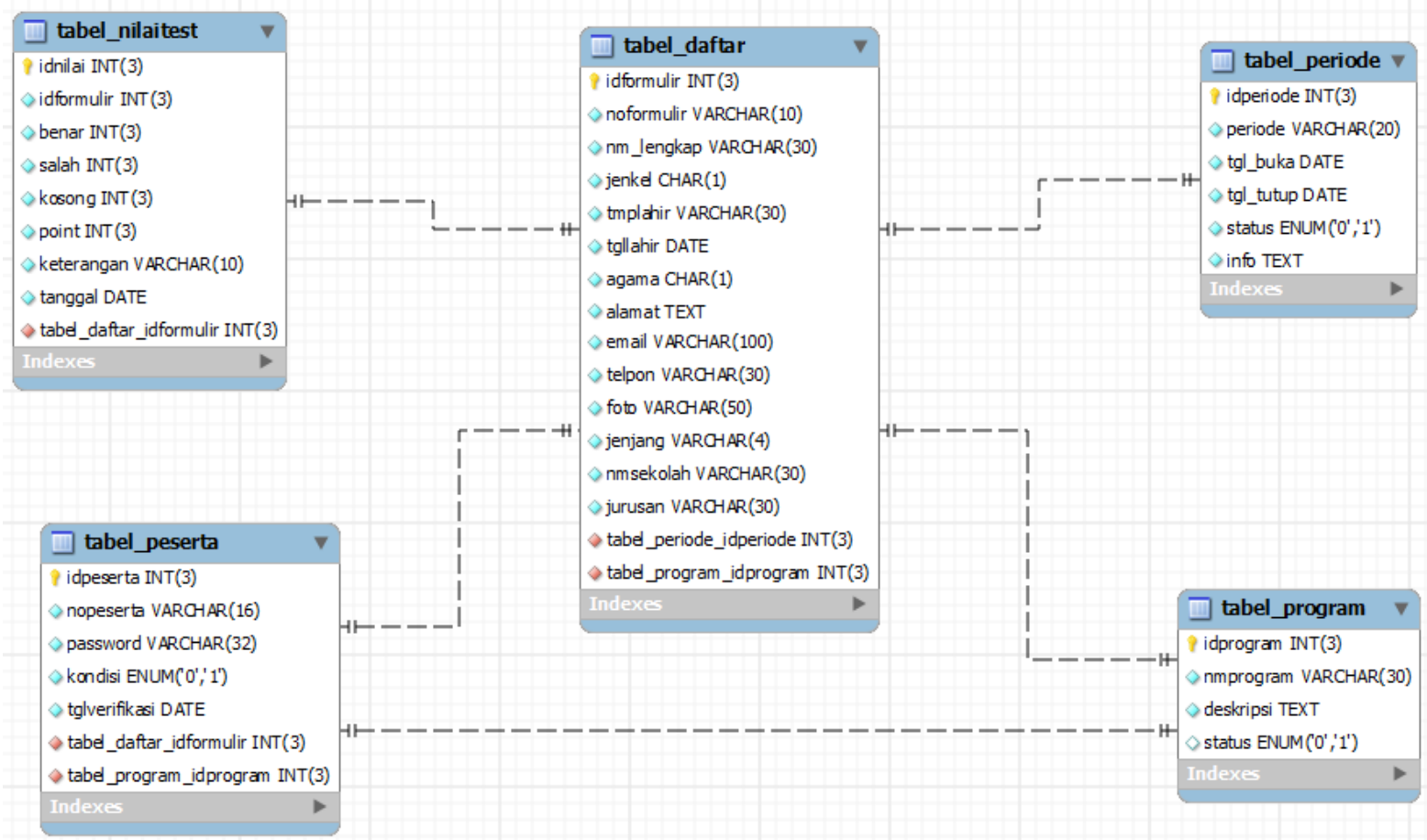

Gambar 10. Logical record structure aplikasi seleksi peserta pelatihan kerja

\subsubsection{Coding (Pengkodean)}

\section{Halaman Depan}

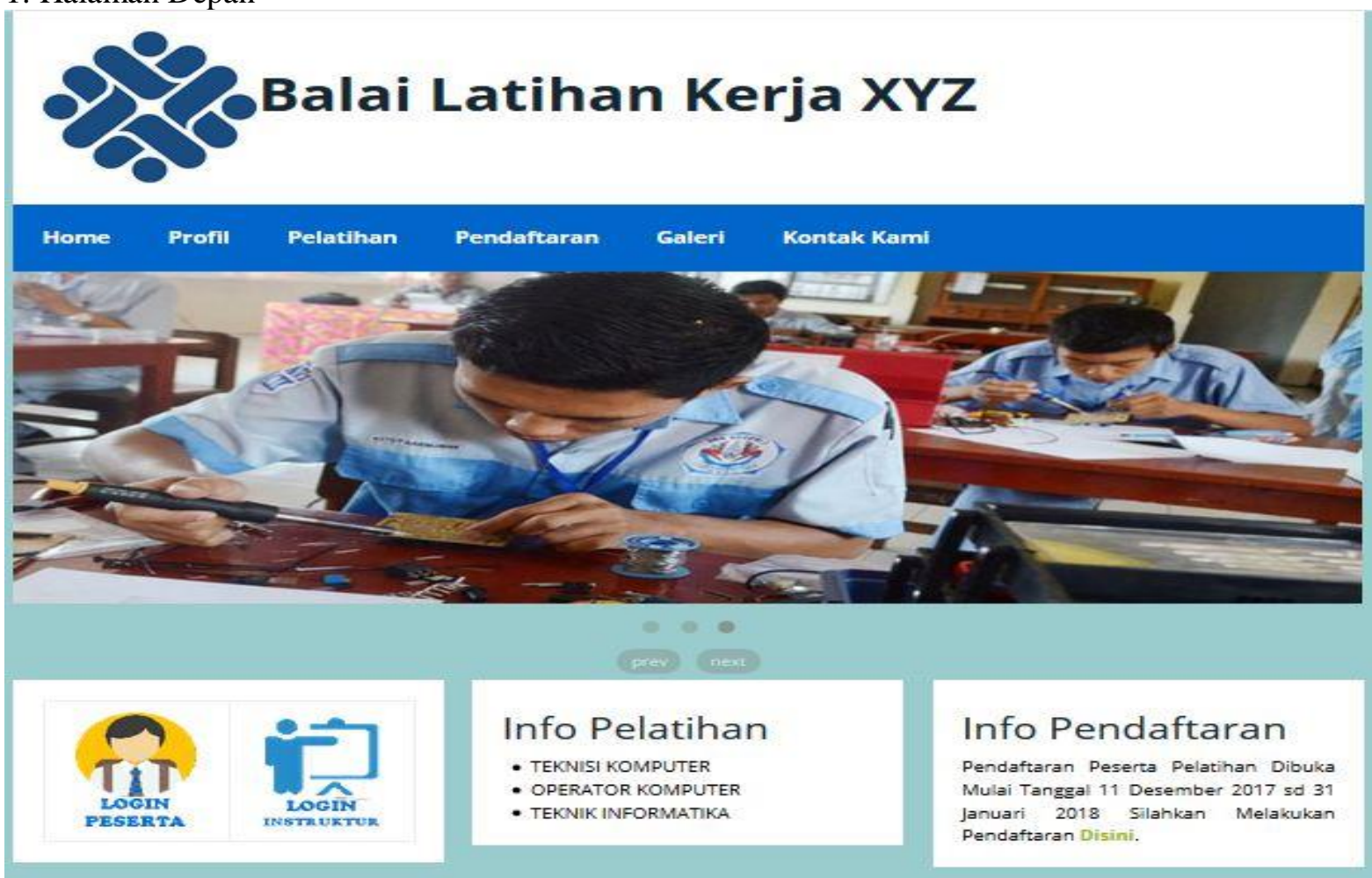

\section{Selamat Datang Di Situs Balai Latihan Kerja XYZ,}

Terima kasih sudah mengunjungi situs resmi Balai Latihan Kerja (BLK) XYZ. Dalam situs ini kami informasikan terkait penerimaan peserta pelatihan kerja, pendaftaran peserta, pelaksanaan ujian seleksi sampai dengan hasil ujian seleksi. Selamat menggunakan situs kami. gunakanlah situs ini dengan bijak

Gambar 11. Halaman depan 
Halaman depan aplikasi seleksi peserta pelatihan kerja berbasis web ini menampilkan beberapa informasi seputar kegiatan pelatihan yang terdiri dari informasi pendaftaran, informasi program pelatihan dan galeri foto kegiatan pelatihan.

\section{Halaman Registrasi}

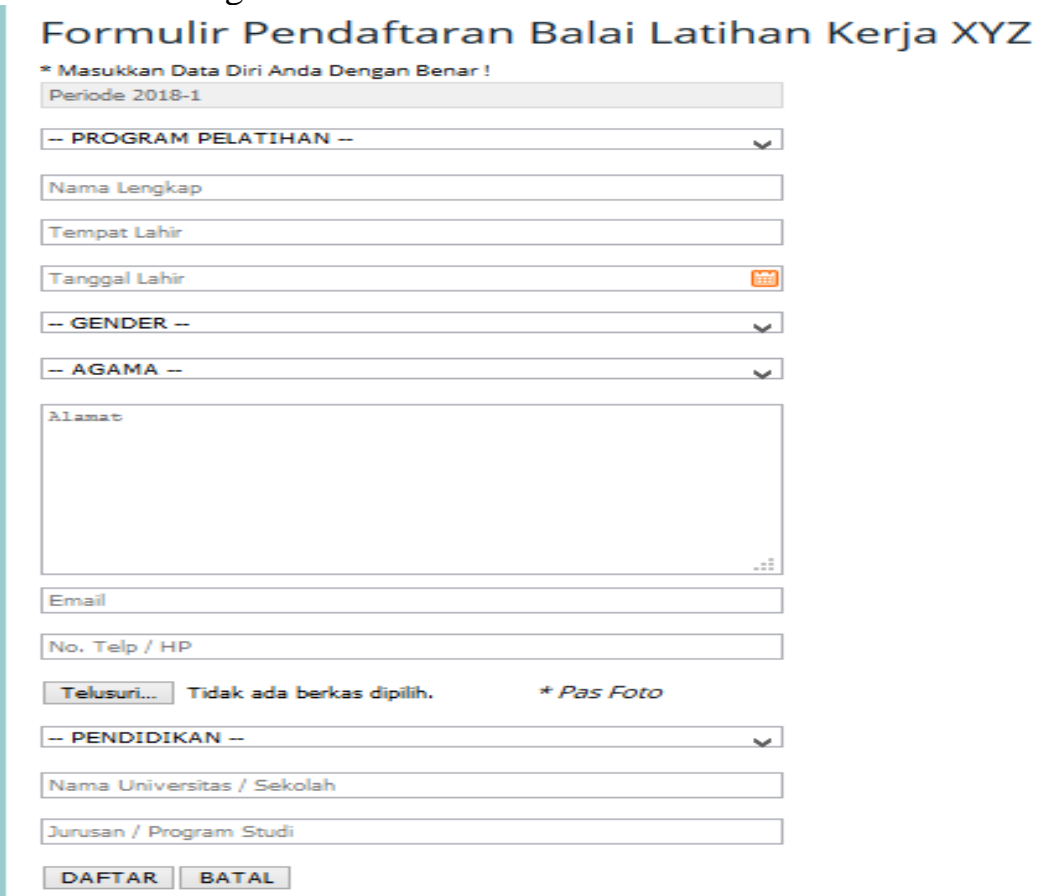

Gambar 12. Halaman pendaftaran

Halaman ini merupakan formulir untuk calon peserta pelatihan yang ingin mendaftarkan sebagai peserta pelatihan, dalam form ini terdapat beberapa validasi yaitu validasi text kosong, email dan nomor telpon untuk memastikan bahwa data yang dimasukkan lengkap dan sesuai formatnya.

\section{Halaman Soal Ujian}

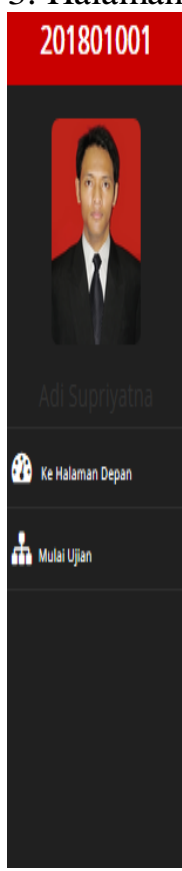

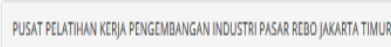

Soal ujäan untuk, Adi Supriyatna

Jawablat percanyasn berikut dengan lepar can cepat.

Selamat mengerijakn, Adi Supryjatha.

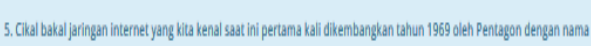

$0_{\text {NPPNET }}$

8. $\mathrm{O}_{\mathrm{wm}}$

c. Onep

0. Onomperse

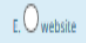

Gambar 13. Halaman soal ujian 
Halaman ini digunakan oleh calon peserta untuk melaksanakan ujian seleksi, dalam halaman ini ditampilkan 30 soal pertanyaan yang diacak. Soal yang ditampilkan adalah pertanyaan mendasar sesuai dengan program pelatihan yang dipilih oleh calon peserta.
Setelah menjawab 30 pertanyaan calon peserta dapat melakukan review jawaban terlebih dahulu sebelum mengirimkan jawaban dan mendapatkan hasil keputusan penerimaan peserta pelatihan.

\section{Halaman Verifikasi}

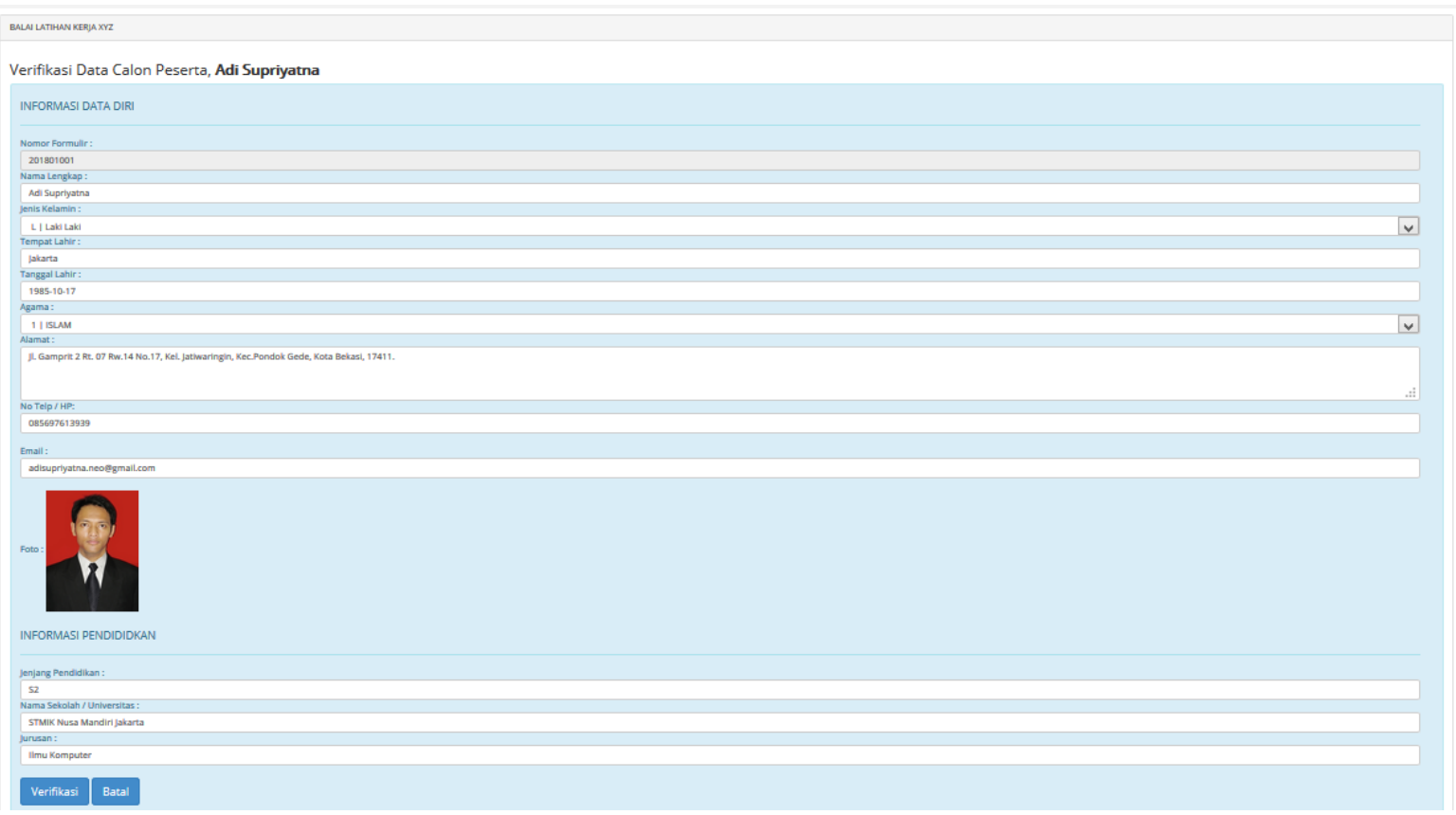

Gambar 14. Halaman verifikasi data peserta

Halaman verifikasi ini ditampilkan oleh sistem jika calon peserta dinyatakan lulus ujian seleksi peserta, dalam halaman ini berisi biodata calon peserta yang sudah dimasukkan pada formulir pendaftaran. Halaman ini disediakan untuk memastikan kembali bahwa data yang dimasukkan calon peserta adalah data yang sesuai.

\section{Halaman Login Admin}

BALAI LATIHAN KERJA
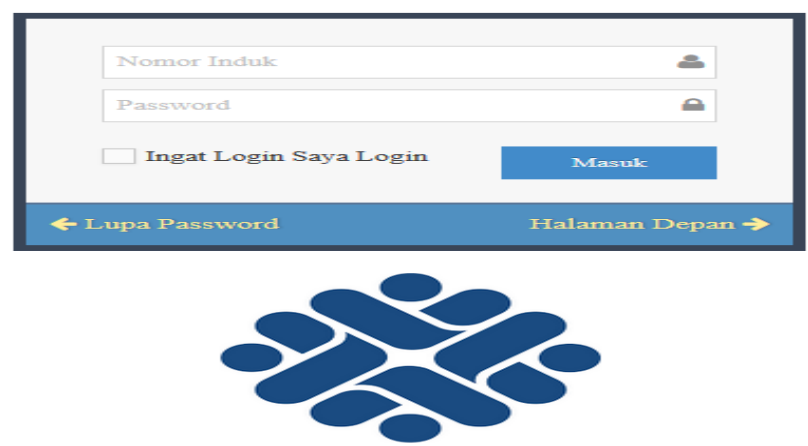

Gambar 15. Halaman login administrator

Halaman login admin digunakan untuk masuk ke ruang admin dengan tujuan untuk keamanan sistem serta menghindari penyalahgunaan data. Admin yang ingin masuk harus memasukkan nomor induk pegawai dan password yang sesuai dengan data yang terdapat pada basis data. Jika admin memasukkan username dan password dengan benar, maka sistem akan mengarahkan ke ruang admin, namun jika salah sistem akan 
menampilkan notifikasi berupa kotak pesan

dan mengarahkan kembali ke halaman depan.

6. Halaman Manajemen Peserta

$\widehat{\Lambda}$ Home > Data Peserta

\section{Data Peserta Pelathan}

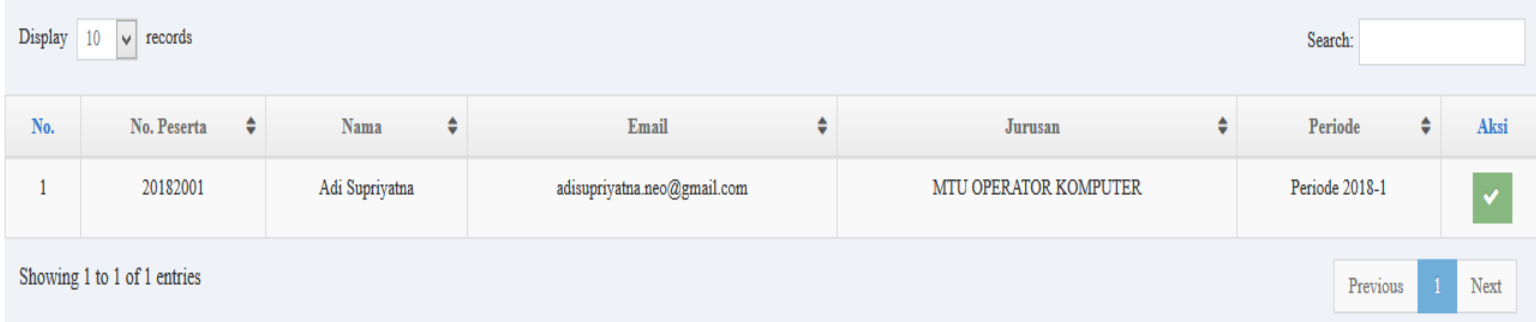

Gambar 16. Halaman data peserta

Pada halaman ini berisi data calon peserta yang sudah dinyatakan lulus seleksi, pada halaman ini admin hanya dapat menampilkan

7. Halaman Manajemen Soal data peserta saja tanpa bisa menambah, merubah maupun menghapus data.

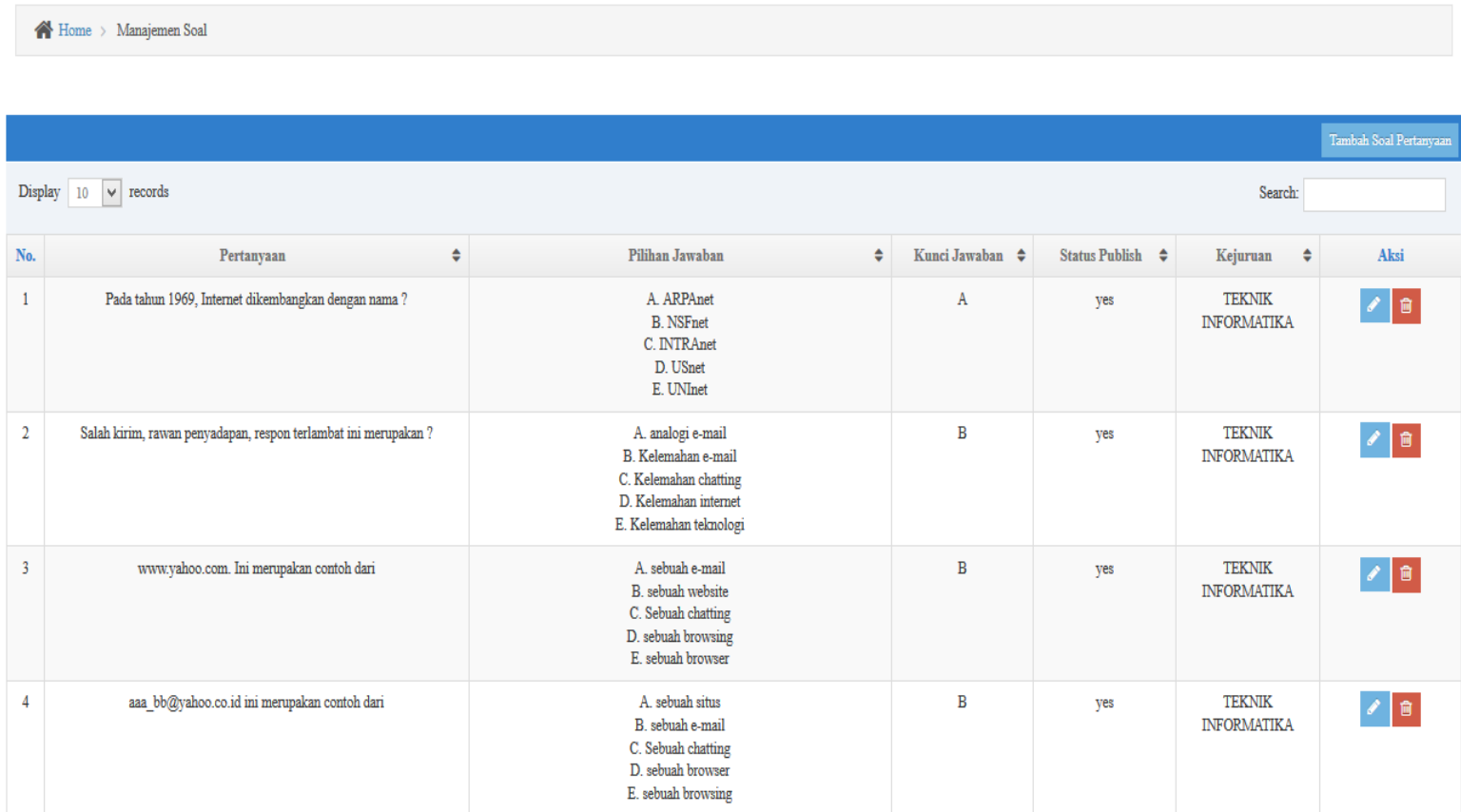

Gambar 17. Halaman manajemen soal ujian.

Halaman ini berisi data soal pertanyaan yang digunakan pada ujian seleksi peserta pelatihan, halaman ini hanya bisa digunakan oleh administrator yang dapat menambah, merubah dan menghapus data. Data soal yang bisa disimpan tidak terhingga, namun soal yang ditampilkan oleh sistem hanya 30 .

\subsubsection{Testing (Pengujian)}

1. Pengujian halaman daftar
Pengujian yang dilakukan pada halaman ini dengan cara menguji masing-masing 
textbox yang terdapat pada form pendaftaran yaitu nama lengkap, tempat lahir, alamat, email, nomor telepon, nama sekolah dan jurusan. Berikut adalah hasil pengujian halaman pendaftaran:

Tabel 1. Pengujian blackbox halaman pendaftaran.

\begin{tabular}{|c|c|c|c|c|}
\hline No & Rancangan Proses & Hasil yang Diharapkan & Hasil & Keterangan \\
\hline 1. & $\begin{array}{l}\text { Mengisi data calon peserta pelatihan } \\
\text { secara lengkap dan sesuai tipenya. }\end{array}$ & $\begin{array}{l}\text { Data calon peserta } \\
\text { tersimpan. }\end{array}$ & Sesuai & $\begin{array}{lr}\text { Jika } & \text { semua } \\
\text { textbox } & \text { diisi } \\
\text { dengan } & \\
\text { lengkap } & \end{array}$ \\
\hline 2. & $\begin{array}{l}\text { Mengisi data calon peserta pelatihan } \\
\text { tidak lengkap. }\end{array}$ & $\begin{array}{l}\text { Sistem akan memberikan } \\
\text { pesan "Mohon lengkapi } \\
\text { data yang dimasukkan!" }\end{array}$ & Sesuai & \\
\hline 3 & $\begin{array}{l}\text { Nomor telpon hanya bisa diinput } \\
\text { dengan angka } 0-9 \text {. }\end{array}$ & $\begin{array}{l}\text { Jika diinput selain angka } \\
\text { textbox tidak dapat terisi. }\end{array}$ & Sesuai & \\
\hline 4 & $\begin{array}{l}\text { Validasi email jika data yang } \\
\text { dimasukkan tidak sesuai format. }\end{array}$ & $\begin{array}{l}\text { Sistem akan memberikan } \\
\text { pesan "Email tidak valid" }\end{array}$ & Sesuai & \\
\hline
\end{tabular}

2. Pengujian halaman login peserta Pengujian pada halaman ini dilakukan pada fungsi validasi username dan password, apakah berjalan sesuai dengan

fungsinya. Berikut adalah hasil pengujian halaman login peserta:

Tabel 2. Pengujian blackbox halaman login peserta

\begin{tabular}{|c|c|c|c|c|}
\hline No & Rancangan Proses & Hasil yang Diharapkan & Hasil & Keterangan \\
\hline 1. & $\begin{array}{l}\text { Masukkan Username dan Password } \\
\text { dengan lengkap lalu klik masuk. }\end{array}$ & $\begin{array}{l}\text { Masuk ke halaman calon } \\
\text { peserta untuk mengikuti } \\
\text { ujian seleksi. }\end{array}$ & Sesuai & \\
\hline 2. & $\begin{array}{l}\text { Username dan password dimasukkan } \\
\text { salah lalu klik masuk. }\end{array}$ & $\begin{array}{l}\text { Sistem memberikan pesan } \\
\text { "Username atau Password } \\
\text { Anda Salah, Silahkan } \\
\text { Ulangi Lagi!" }\end{array}$ & Sesuai & \\
\hline 3. & $\begin{array}{l}\text { Username atau password } \\
\text { dikosongkan lalu klik masuk. }\end{array}$ & $\begin{array}{l}\text { Sistem memberikan pesan } \\
\text { "Masukkan Username dan } \\
\text { Password Anda!" }\end{array}$ & Sesuai & \\
\hline
\end{tabular}

3. Pengujian halaman login admin. Pengujian pada halaman ini dilakukan pada fungsi validasi NIK dan password, apakah berjalan sesuai dengan fungsinya.
Berikut adalah hasil pengujian halaman login administrator:

Tabel 3. Pengujian blackbox halaman login administrator

\begin{tabular}{|c|c|c|c|c|}
\hline No & Rancangan Proses & Hasil yang Diharapkan & Hasil & Keterangan \\
\hline 1. & $\begin{array}{l}\text { Masukkan NIP dan Password dengan } \\
\text { lengkap lalu klik masuk. }\end{array}$ & $\begin{array}{lcl}\text { Masuk ke } & \text { halaman } \\
\text { Administrator. } & \end{array}$ & Sesuai & \\
\hline 2. & $\begin{array}{l}\text { NIP dan password dimasukkan salah } \\
\text { lalu klik masuk. }\end{array}$ & $\begin{array}{l}\text { Sistem memberikan pesan } \\
\text { "NIP atau Password Anda } \\
\text { Salah, Silahkan Ulangi } \\
\text { Lagi!" }\end{array}$ & Sesuai & \\
\hline 3. & $\begin{array}{l}\text { NIP atau password dikosongkan lalu } \\
\text { klik masuk. }\end{array}$ & $\begin{array}{l}\text { Sistem memberikan pesan } \\
\text { "Masukkan NIP dan } \\
\text { Password Anda!" }\end{array}$ & Sesuai & \\
\hline
\end{tabular}

4. Pengujian Halaman Input Soal
Pengujian yang dilakukan pada halaman ini dengan cara menguji masing-masing 
textbox yang terdapat pada form soal yaitu pertanyaan, pilihan jawaban dan kunci jawaban. Berikut adalah hasil pengujian halaman input soal:

Tabel 3. Pengujian blackbox halaman input soal ujian

\begin{tabular}{|c|c|c|c|c|}
\hline No & Rancangan Proses & Hasil Yang Diharapkan & Hasil & Keterangan \\
\hline 1. & $\begin{array}{l}\text { Masukkan soal pertanyaan, pilihan } \\
\text { jawaban dan kunci jawaban dengan } \\
\text { lengkap lalu klik simpan data. }\end{array}$ & $\begin{array}{l}\text { Data soal pertanyaan } \\
\text { disimpan kedalam basis } \\
\text { data. }\end{array}$ & Sesuai & \\
\hline 2. & $\begin{array}{l}\text { Semua textbox dikosongkan lalu klik } \\
\text { simpan data. }\end{array}$ & $\begin{array}{l}\text { Sistem memberikan pesan } \\
\text { notifikasi "Masukkan soal } \\
\text { dan jawaban secara } \\
\text { lengkap" }\end{array}$ & Sesuai & \\
\hline 3. & $\begin{array}{l}\text { Salah satu atau beberapa textbox } \\
\text { tidak diisi lalu klik simpan. }\end{array}$ & $\begin{array}{l}\text { Sistem memberikan pesan } \\
\text { notifikasi "Masukkan soal } \\
\text { dan jawaban secara } \\
\text { lengkap" }\end{array}$ & Sesuai & \\
\hline
\end{tabular}

\subsubsection{Software Increment}

Setelah dilakukan implementasi sistem aplikasi ujian seleksi peserta pelatihan kerja kemudian dilakukan kegiatan monitoring dan evaluasi terhadap sistem yang diterapkan, untuk kemudian dilakukan pengembangan terhadap aplikasi ujian seleksi peserta pelatihan kerja. Setelah dilakukan monitoring dan evaluasi maka untuk pengembangan sistem selanjutnya, sistem ini akan dikembangkan dengan membuat sistem informasi balai latihan kerja yang mencakup data dan informasi terkait kegiatan pelatihan kerja dimulai dari informasi jadwal pelatihan, sistem absensi, sistem penilaian sampai dengan pencetakan surat keterangan.

\section{PENUTUP}

Berdasarkan hasil penelitian yang telah dilakukan ditemukan bahwa aplikasi ujian seleksi peserta pelatihan kerja dapat memberikan kemudahan kepada masyarakat untuk mendapatkan informasi terkait pelaksanaan pelatihan, memudahkan dalam melakukan pendaftaran dan melaksanakan ujian seleksi peserta pelatihan kerja. Metode Extreme Programming (XP) dapat digunakan untuk membangun atau mengembangkan perangkat lunak. Agar aplikasi ini berjalan sesuai dengan fungsinya oleh karena itu perlu dibuatkan standarisasi berupa petunjuk teknis penggunaan. Untuk penelitian berikutnya dalam mengetahui apakah aplikasi ini sudah diterima masyarakat dan memberikan kepuasan terhadap pengguna maka perlu dilakukannya evaluasi dengan menggunakan metode yang ada.

\section{DAFTAR PUSTAKA}

[1] Ivancevich, John, M. Dkk. 2008. Perilaku dan Manajemen Organisasi. Jilid 1 dan 2. Jakarta: Erlangga.

[2] Dessler, Gary. 2009. Manajemen Sumber Daya Manusia. Jakarta: Index.

[3] Susanto, Azhar. 2013. Sistem Informasi Akuntansi. Bandung: Lingga Jaya.

[4] Mulyanto, Agus. 2009. Sistem Informasi Konsep dan Aplikasi. Yogyakarta: Pustaka Pelajar.

[5] Sunyto, Agus. 2008. Manajemen Sumber Daya Manusia. Jakarta: Badan Penerbit IPWI.

[6] Ependi, Usman. Qoriani Widayati. 2014. Extreme Programming Study Method Case Study on Designing of Accounting Term Dictionary. International Conference on Engineering \& Technology Development 2014. hh. 5255.

[7] Nugroho, Adi. 2010. Rekayasa Perangkat Lunak Berorientasi Objek dengan Metode USDP. Yogyakarta: Andi.

[8] Prabowo, Sonny Ariyanto. Sholiq. Feby Artwodini Muqtadiroh. 2013. Rancang Bangun Aplikasi Web Informasi Eksekutif Pada Pemerintah Kabupaten XYZ. Jurnal Teknik Pomits Vol. 2 No.3. hh. A-476 - A-480.

[9] Ayu, Wulan. Ilham Perdana. 2014. Perancangan Sistem Informasi Rekrutmen dan Seleksi Karyawan Berbasis Web Di PT. Qwords Company 
International. Jurnal Manajemen

Indonesia. Vol. 14 No.3. hh. 247-256.

[10] Setiawan, Fuad Indra. Adiningsih, Astrid Retno. Widayat, Widi. Wijayanto, Feri. 2012. Pengembangan Sistem Informasi Manajemen Rekrutmen Asisten Laboratorium. Seminar Nasional Aplikasi Teknologi Informasi 2012.

\section{Hak Cipta}

Semua naskah yang tidak diterbitkan, dapat dikirimkan di tempat lain. Penulis bertanggung jawab atas ijin publikasi/pengakuan gambar, tabel dan bilangan dalam naskah yang dikirimkannya. Naskah bukanlah naskah jiplakan dan tidak melanggar hak-hak lain dari pihak ketiga. Penulis setuju bahwa keputusan untuk menerbitkan/ tidak menerbitkan naskah dalam jurnal yang dikirimkan penulis, adalah sepenuhnya hak Pengelola. Sebelum penerimaan terakhir naskah, penulis diharuskan menegaskan secara tertulis, bahwa tulisan yang dikirimkan merupakan hak cipta penulis dan menugaskan hak cipta ini pada pengelola. 